\title{
ЦИВІЛЬНО-ПРАВОВІ АСПЕКТИ ЩОДО ОТРИМАННЯ ЗГОДИ НА ПОСМЕРТНЕ ДОНОРСТВО
}

\author{
ОЛІЙНИК Роман Володимирович - аспірант кафедри цивільного права та \\ процесу юридичного факультету Львівського національного університету імені \\ Івана Франка
}

УДК 347.132-021.37(477):[347.56:364.2:615.38](043.5) О-54 DOI 10.32782/LAW.2020.2.24

\begin{abstract}
Стаття присвячена проблемам отримання згоди на посмертне донорство. Здійснено аналіз двох основних моделей отримання згоди, які використовуються в міжнародній практиці.

Моделі отримання згоди на посмертне донорство регулюють порядок проведення вилучення органів за життя потениійного донора.

Існуючий в начіональному законодавстві порядок отримання згоди на посмертне донорство поєднує в собі характеристики двох основних моделей. Це породжує ряд суперечностей на практиці. У зв'язку з ичм сббормульовано висновки та пропозииї щодо удосконалення нащіонального законодавства.
\end{abstract}

Ключові слова: донор, донорство, трансплантація, презумпиія, модель згоди.

Аналіз законодавства країн, які використовують трансплантацію, як спосіб лікування захворювань, та України вказує на існування двох основних підходів до вирішення даного питання щодо вилучення органів у мертвих осіб - двох презумпцій, одна з них дозволяє провести вилучення органів з тіла особи у випадку, якщо за життя вона не висловлювала такої заборони у встановленому порядку. В національній юридичній науці вона носить назву презумпція згоди, а у міжнародних документах - «допустимою» [2], або «optung (or contracting) out»).

Інша презумпція передбачає отримання згоди особи на посмертне донорство за життя. Її ще називають презумпцією незгоди, а у міжнародних документах - «чітко вираженою» [2], або «opting in»). Характерним для них обох є те, що наявність прижиттєвої заборони на вилучення анатомічних матеріалів людини, не дозволяє його проводити.

Науковці вважають, що процес отримання згоди на вилучення органів, як і раніше, є основним чинником, що стримує розвиток донорства.

Разом $з$ тим, як стверджує Р.Д. Ляшенко, кожна презумпція має характерну лише їй функцію, спрямовану на захист прав та інтересів суб'єктів правовідносин [9]. Наведені презумпції, гарантують право особи віддати свої органи після смерті, одночасно охороняючи іï право відмовитися від такого вилучення. Про це може свідчити їх «життєздатність» і успішне застосування на практиці в країнах-лідерах 3 трансплантації [10].

Міжнародне законодавство, залежно від соціальних, медичних і культурних традицій, надає право країнам самим визначати процес отримання та реєстрації згоди на анатомічні матеріали людини.

В основі законодавства про донорство та трансплантацію ряду країн Европи, зокрема, як вже зазначалось вище Австрії, Білорусії, Російської Федерації, Франції та Швейцарії лежить принцип «презумпції згоди» [3]. Згідно 3 даним принципом, якщо особа за життя особисто не заявляла про своє небажання вилучення у неї після смерті ії органів, тканин чи клітин, то вона стає потенційним донором. Після смерті потенційного донора лікарі мають право, без повідомлення близьких осіб та родичів, вилучати анатомічні матеріали з тіла покійного. 
Перевагами даного підходу є перш за все його ефективність для цілей клінічної трансплантації, яка веде до збільшення кількості донорського матеріалу [15].

Про доцільність використання саме такої системи стверджує Д.С. Береговцова, оскільки вона збільшуе можливість отримання донорських органів. У даному випадку, на думку вченої, необхідно надавати перевагу порятунку життя потенційного реципієнта, аніж захисту права недоторканості покійного [4].

На думку B.M. Пашкова застосування такого правового принципу в Україні суперечило 6 пункту 5 Декларації стосовно трансплантації людських органів, прийнятій Всесвітньою медичною асамблеєю у 1987 році [11], згідно з якою обов'язковим є як можна більш повне обговорення запропонованої процедури з донором та реципієнтом або їх довіреними родичами чи юридичними представниками. Вважаємо, що така думка є хибною, оскільки повний аналіз статті 5 вказаної декларації вказує на те, що вона стосується прижиттєвого донорства.

Разом 3 тим, багато хто згоден $з$ тим, що принцип згоди належить до добровільної системи, оскільки все одно зберігається правовий механізм явної відмови від дарування [5].

Протилежним «принципу згоди» 6 «принцип незгоди» - якщо фізична особа ще за життя виявила свою волю щодо вилучення органів та інших анатомічних матеріалів з ії тіла після смерті, ніяких труднощів не виникає, але якщо вона не залишила такого розпорядження, вилучення не допускається, якщо тільки на це не буде згоди від члена сім'ї чи близького родича. Вказана презумпція представлена двома моделями: «моделлю вузької згоди» та «моделлю розширеної згоди».

На думку А.М. Петруня та Т.С. Коваленко втілення в законодавстві про донорство «презумпції незгоди» забезпечує реалізацію природних прав і захист законних інтересів громадян. Aле застосування цієї моделі ускладнює розвиток медицини i використання іiі досягнень у практичній охороні здоров'я [12].

Згідно 3 «моделлю вузької згоди» для того аби вилучити анатомічні матеріали в трупа слід мати чітко виражену на це згоду особи, надану за життя. В Европі ця модель не застосовується, оскільки без юридичної згоди вилучити органи в особи неможливо, а це в свою чергу зменшить кількість потенційних донорів.

«Модель розширеної згоди» передбачає отримання дозволу на вилучення анатомічних матеріалів після смерті як від самого донора за його життя, так і після його смерті - від його родичів чи членів сім’ї, за умови, що він за життя проти цього не заперечував. Стосовно цієї моделі є думки, які їі як підтримують, так і заперечують. Однак, всі аргументи, як на ії користь, так і проти неї, стосуються філософського та етичного питання вирішення долі тіла особи після ії фізичної смерті. На підтримку вказаної моделі свідчить те, що вона значно розширює кількість потенційних донорів порівняно $з$ попередньою «моделлю вузької згоди». Однак, при цьому може статись, що для родичів власні уявлення про це будуть важливішими за уявлення померлого. Довірити вирішення цього питання родичеві означає довірити його іншій людині [16], оскільки на його думку визначальний вплив матиме позиція лікаря.

За життя кожна людина має право заперечувати проти пересадки іï органів і тканин. Питання донації (пожертви) вирішує донор. Трансплантація тканин і органів від трупів допустима тільки за згодою цього при житті, тобто слід враховувати прижиттєву волю померлого.

В наукових працях виділяють також третю модуль - «інформаційну модель», згідно із якою в разі, відсутності вираженої чіткої прижиттєвої волі потенційного донора, після його смерті родичам чи близьким такої особи надається право прийняти рішення про вилучення 3 тіла покійного анатомічних матеріалів. У випадку, якщо протягом наданого їм часу, вказані особи не надають згоди, але й не висловлюють заперечення, з тіла доноратрупа можуть вилучатись анатомічні матеріаи. В країнах, де діє такий принцип, надання згоди допускається в усній формі або шляхом фіксації в медичній картці чи реєстрі донора, водійських правах чи посвідченні особи, або картці донора.

Стосовно законодавства про донорство та трансплантацію України, то в ньому поєднуються два принципи - «згоди» та «незгоди».

Такий висновок можна зробити із змісту статті 290 ЦК України та Закону України 


\section{Цивільне, підприсмницьке, господарське та трудове право}

«Про застосування трансплантації анатомічних матеріалів людині». Основи законодавства про охорону здоров' я містять лише деякі положення щодо пересадки органів і тканин, вилучених у живого донора [1].

Так, частина 3 статті 290 ЦК України, частина 3 статті 47 Закону України «Основи законодавства про охорону здоров'я» та частина 4 статті 14 та частина 1 статті 16 Закону України «Про застосування трансплантації анатомічних матеріалів людині» визначають, що кожна повнолітня дієздатна особа може дати письмову згоду або незгоду стати донором анатомічних матеріалів. Зазначене положення потрібно визнати взагалі некоректним, оскільки його використання створює колізію у правовому регулюванні. Саме тому різняться думки вчених з приводу моделі презумпції, що діє в Україні. Таке ж твердження підтримує Б.Ю. Пипченко, який зазначає, що аналізуючи вищезазначену норму, можна зробити висновок, з одного боку, про існування «презумпції згоди», проте, 3 іншого - про «презумпцію незгоди» [13].

На думку С.В. Гринчака в Україні діє модель «інформаційної згоди» [6]. Таку ж модель по суті визнає й I.P. Пташник, але називає ії при цьому «інформативною згодою» та прирівнює до «презумпції незгоди» [14]. Існування в нашій державі «презумпції незгоди» підтримує С.Г. Стеценко. Така юридична модель передбачає, що донор має право за життя написати заяву про свою згоду чи незгоду на використання власних органів на випадок своєї смерті. Тобто, якщо особа за життя не висловила згоду на трансплантацію iii анатомічних матеріалів, презюмується, що вона забороняе проводити трансплантацію. Такий дозвіл можуть надати й інші особи, визначені законом: подружжя або в одного з близьких родичів цієї особи (діти, батьки, рідні брати та сестри), а також законні представники неповнолітніх, недієздатних, обмежених в дієздатності осіб.

Кожна повнолітня дієздатна особа має також право призначити свого повноважного представника, який після смерті цієї особи надасть згоду на вилучення 3 іï тіла анатомічних матеріалів для трансплантації та/або виготовлення біоіплантатів. Повноважним представником може бути лише повнолітня дієздатна особа, яка свідомо та добровільно надала згоду.

У разі смерті особи віком до 18 років згода на вилучення анатомічних матеріалів 3 тіла цієї особи для трансплантації та/або виготовлення біоімплантатів може бути надана батьками або іншими законними представниками цієї особи.

Аналіз статті 16 Закону України «Про застосування трансплантації анатомічних матеріалів людині» вказує не окремі недоліки iii конструкції. Так, зі змісту частини 11 даної статті незрозумілим є у кого в першу чергу повинна запитуватись згода на отримання анатомічних матеріалів людини в разі відсутності прижиттевої згоди на донорство та не призначення покійним за життя повноваженого представника - у другого 3 подружжя або в одного з близьких родичів цієї особи (дітей, батьків, рідних брата та сестри), чи повинен трансплант-координатор запитувати згоду в одного з батьків, чи у обох. 3 урахуванням викладеного, можуть бути випадки, коли один 3 подружжя надасть згоду на вилучення органів, а хтось з близьких родичів буде заперечувати, чи навпаки. 3 метою уникнення таких ситуацій слід встановити чітку ієрархію надання такої згоди. Доречно, щоб більшу юридичну силу мала згода одного з подружжя. В разі не отримання, як згоди, так і незгоди, від другого $з$ подружжя, дозвіл повинен запитуватись в батьків потенційного донора. Після цього, за аналогічним принципом згоду слід запитувати в дітей, а потім в рідного брата чи сестри.

Враховуючи викладене, в разі застосування і в подальшому моделі отримання згоди на посмертне донорство, закріпленій в чинному Законі України «Про застосування трансплантації анатомічних матеріалів людині», вважаємо за доцільне внести в статтю 16 цього закону зміни, які б встановили ієрархічність отримання згоди на посмертне донорство від одного з подружжя та близьких родичів.

Дискусійним є питання отримання анатомічних матеріалів у осіб, смерть яких наступила в місцях позбавлення волі, під час затримання в порядку адміністративного чи кримінального провадження, або під час застосування до неї запобіжного заходу у вигляді тримання під вартою або стягнення у 
вигляді адміністративного решту. Вважаємо, що у вказаної категорії осіб, які за життя - до поміщення в місця позбавлення волі, обрання стосовно неї запобіжного заходу у вигляді тримання під вартою, затримання в порядку адміністративного чи кримінального провадження, надали згоду на посмертне донорство, вилучення анатомічних матеріалів повинно проводитись. Разом 3 тим, 3 метою попередження зловживань зі сторони представників державних органів, рішення про вилучення таких органів повинно прийматись консиліумом лікарів в складі не менше 3 лікарів, які не працюють лікарями в установах, де утримувались особи за життя.

У зв’язку із цим, пропонуємо внести зміни в частину 1 статті 16 Закону України «Про застосування трансплантації анатомічних матеріалів людині», виклавши ії̈ наступним чином:

«Кожна дієздатна особа за життя має право надати письмову згоду або незгоду на вилучення анатомічних матеріалів 3 ії тіла для трансплантації та/або виготовлення біоімлантатів після визначення ії стану як незворотна смерть (смерть мозку або біологічна смерть) відповідно до закону (далі - згода або незгода на посмертне донорство). В разі відсутності такої письмово засвідченої прижиттєвої незгоди, після констатації ії стану як незворотна смерть (смерть мозку або біологічна смерть) ії̈ органи можуть бути донорськими.

У померлих недієздатних чи обмежено дієздатних осіб, анатомічні матеріали можуть бути отримані лише за письмовою згодою обох батьків або уповноважених представників».

Наскільки прийнятна для українського суспільства та чи інша правова концепція отримання біологічного матеріалу широко обговорюється медичною та правовою громадськістю шляхом проведення конгресів [7] та круглих столів на предмет прав людини у сфері трансплантації [8].

Вважаємо, що модель отримання згоди на донорство, яка діє в Україні є надто громіздкою, а враховуючи загальну необізнаність громадян у питаннях донорства, ще і непрактичною, такою, яка не стимулює розвиток трансплантації.

Застосування в Україні змішування «презумпції згоди» та «презумпції незгоди» галь- мує розвиток донорства та трансплантації. На нашу думку застосування в Україні «змішаної» моделі отримання згоди є недоцільним, оскільки вона створює ряд бюрократичних перешкод, ставить ії в залежність від ефективного функціонування електронних реєстрів отримання та своєчасного обліку згоди на посмертне донорство, необхідність з'ясування та врахування не лише прижиттєвої волі донора-трупа, але і його родичів та членів сім'ї, інтереси яких не завжди будуть співпадати. Найоптимальнішою, на нашу думку, є модель чи презумпція «згоди».

\section{Література}

1. Закон України „Основи законодавства України про охорону здоров'я" від 19.11.1992 р. №2801-XII (в редакції Закону від 27.11.2003 р.)// ВВР. - 1993. - №4. - ст.19.

2. Керівні принципи ВООЗ 3 трансплантації людських клітин, тканин та органів. [Електронний ресурс]. - Режим доступу: https://www.who.int/transplantation/publications/ en/. (дата звернення 19.01.2020).

3. Анікіна Г. Особливості правового регулювання трансплантації органів від померлого донора/Г.Анікіна//Юридична Україна. - 2010. - № 10 - С. 69. [Електронний ресурс]. - Режим доступу: https://www.google.com/ search?client $=$ firefox $-\mathrm{b}-\mathrm{d} \& \mathrm{cq}=\% \mathrm{D} 0 \% \mathrm{~B} 0 \% \mathrm{D} 0 \% \mathrm{~B}$ D\%D1\%96\%D0\%BA\%D1\%96\%D0\%BD\%D0\%B 0+\%D0\%93.+\%D0\%BE\%D1\%81\%D0\%BE\%D 0\% B 1\% D0\%B B\%D0\% B 8\% D0\% B2\% D0\%BE\% $\mathrm{D} 1 \% 81 \% \mathrm{D} 1 \% 82 \% \mathrm{D} 1 \% 96+\% \mathrm{D} 0 \% \mathrm{BF} \% \mathrm{D} 1 \% 80 \%$ $\mathrm{D} 0 \% \mathrm{~B} 0 \% \mathrm{D} 0 \% \mathrm{~B} 2 \% \mathrm{D} 0 \% \mathrm{BE} \% \mathrm{D} 0 \% \mathrm{~B} 2 \% \mathrm{D} 0 \% \mathrm{BE} \%$ D0\%B3\%D0\%BE+\%D1\%80\%D0\%B $5 \% \mathrm{D} 0 \% \mathrm{~B} 3$ $\% \mathrm{D} 1 \% 83 \% \mathrm{D} 0 \% \mathrm{BB} \% \mathrm{D} 1 \% 8 \mathrm{E} \% \mathrm{D} 0 \% \mathrm{~B} 2 \% \mathrm{D} 0 \% \mathrm{~B} 0$ $\% \mathrm{D} 0 \% \mathrm{BD} \% \mathrm{D} 0 \% \mathrm{BD} \% \mathrm{D} 1 \% 8 \mathrm{~F}$. (дата звернення 19.01.2020).

4. Береговцова Д. С. Трансплантация органов и тканей и права человека//Вестник Полоцкого государственного университета. Серия D : Экономические и юридические науки. Новополоцк, 2010. № 4. - С. 234-239

5. Волкова О.О. Уніфікація норм про дарування органів для трансплантації в рамках міжнародного права. Юридична Україна, № 5, - 2012. - С. 92.

6. Гринчак С. В. Моделі правового регулювання вилучення органів або тканин у померлих осіб// Наукові праці Національного 


\section{Цивільне, підприсмницьке, господарське та трудове право}

авіаційного університету. Серія: Юридичний вісник «Повітряне і космічне право». Київ, 2013. T. 3, № 28. C. 142.

7. Кашинцева О.Ю. Право біоетики та медичне право: новий напрямок наукових досліджень Київського університету права НАН України. Часопис Київського університету права, № 4, - 2009. - С. 204.

8. Круглий стіл на тему: «Права людини у сфері трансплантології: європейський правовий концепт». Часопис Київського університету права, № 4, - 2012. - С. 438.

9. Аяшенко Р. Д. Презумпція у праві: питання теорії та практики: дис. ... канд. юрид. наук: 12.00.01. - Київ, - 2011. - С. 74.

10. Обухова Т. Трансплантология - шанс выжить//Здоровье Украины. 2000. № 11. C. 56.).

11. Пашков В. Трансплантація органів померлої людини: господарсько-правова регламентація/Медичне права: наук.-практ. ж-л/ Гол. ред. І.Я. Сенюта. - 1 (13) 2014. - Київ: редакція журналу «Право України». - 2014. C. 38 .

12. Петруня А., Коваленко Т. Реформування законодавства в галузі трансплантації: медичні та правові аспекти//Право України: юридичний журнал/Гол. ред.: О.Д. Святоцький. - 7/2013. - Київ: Редакція журналу «Право України». - 2013. - С. 314.

13. Пипченко Б. Ю. Дискусійні аспекти надання згоди на донорство органів та тканин для трансплантації//Медичне право України: правовий статус пацієнтів в Україні та його законодавче забезпечення (генезис, розвиток, проблеми і перспективи вдосконалення): матеріали II Всеукр. наук.-практ. конф., (17-18 квіт. 2008 року. м. Аьвів). - Аьвів, - 2008. C. 236.

14. Пташник I. Р. Цивільно-правове регулювання трансплантації в Україні: дис... канд. юрид. наук: спец. 12.00.03 «Цивільне право; цивільний процес; сімейне право; міжнародне приватне право» / I.P. Пташник. - K., - 2016. - C. 45.

15. Саєнко В.Ф., Костенко А.А. Современное состояние трансплантации органов в Украине //В.Ф. Саєнко, А.А. Костенко// Doctor. Журнал для практикуючих врачей. - 2004. №4.- C. 14-16.

\section{SUMMARY}

Analysis of the legislation of foreign countries and Ukraine indicates the existence of two main approaches to resolving the issue of obtaining consent for the removal of organs from dead persons - two presumptions. One of them allows you to remove organs from a person's body if he has not expressed such a ban in his lifetime. In national jurisprudence, such a presumption is called a "presumption of consent." The other involves obtaining a person's consent to posthumous donation for life. It is also called the "presumption of disagreement." Characteristic of both of them is that the presence of a lifetime ban on the removal of human anatomical materials does not allow it to be carried out.

During life, everyone has the right to object to the transplantation of its organs and tissues. The issue of donation is decided by the donor. Transplantation of tissues and organs from corpses is permissible only with the consent obtained during life.

The legislation on donation and transplantation in Ukraine combines two principles - "consent" and "disagreement". This conclusion can be drawn from the content of Article 290 of the Civil Code of Ukraine and the Law of Ukraine "On the use of transplantation of anatomical materials to humans."

Relevant for the national legislation is the issue of obtaining consent for posthumous donation from the relatives of the deceased, as well as the donation of persons detained in places of imprisonment.

The model of obtaining a donation agreement, which operates in Ukraine, is too cumbersome and impractical. It inhibits the development of donation and transplantation. The model or presumption of "consent" is the most optimal.

In this regard, conclusions and proposals for improving national legislation have been defined.

Key words: donor, donation, transplantation, presumption, consent model.

16. Чеботарьова Г.В. Проблема правового регулювання донорства органів в Україні/ Часопис Київського університету права: укр. наук.-теорет. ч-с/Гол. ред. Ю.С. Шемшученко. - К.: Київський університет права, - 2020. № 4. - С. 57. 